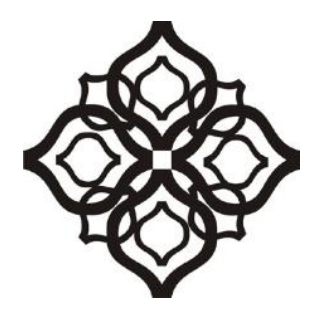

Shirkah

Journal of Economics and Business 
Shirkah: Journal of Economics and Business

Volume 5, No. 3, September-December 2020

ISSN: 2503-4235 (p); 2503-4243 (e)

\section{Table of Contents}

Institutional Quality and Sukuk Development: A Study of Five 286 OIC Countries

Nuhbatul Basyariah, Hadri Kusuma, Ibnu Qizam

Performance of GoFood MSEs Partnership: An Integration of

Entrepreneurial Orientation, Marketing Capabilities, and

Brand Orientation

Septi Kurnia Prastiwi, Asep Maulana Rohimat

Islamic Social Reporting Disclosure of Sharia Commercial

Banks in Indonesia: A Form of Social Responsibility

Riduwan, Lu'liyatul Mutmainah, Rofiul Wahyudi

Concentration and Specialization of Economic Activities in the 362

Kingdom of Saudi Arabia

Salim Bourchid Abdelkader, Hamidouche M'hamed, Abderrazak

Ahmed Zian

Indonesian Islamic Commercial Banks' Efficiency: A Stochastic 386 Frontier Analysis

Sylva Alif Rusmita, Devy Ariesta Putri

Islamic Economics Development in Indonesia: Reflection on

Contemporary Thoughts of Muslim Intellectuals

Zainal Abidin 


\title{
Indonesian Islamic Commercial Banks' Efficiency: A Stochastic Frontier Analysis
}

\author{
Sylva Alif Rusmita* \\ Faculty of Economics and Business, Universitas Airlangga, Indonesia \\ *Corresponding author: sylvalifr@feb.unair.ac.id \\ Devy Ariesta Putri \\ Faculty of Economics and Business, Universitas Airlangga, Indonesia \\ devyariesta9@gmail.com
}

\begin{abstract}
Islamic banks in Indonesia are continuously experiencing a rapid growth; thus, it results in a competitive financial sector. Consequently, maintaining an excellent performance is a prerequisite to gain customers' trust and loyalty, one of the ways is enhancing productivity and efficiency performance. Drawing on this issue, the present study aims to examine the efficiency of Islamic banks listed in the Financial Services Authority (OJK) in the period of 2015 to 2019. Employing Stochastic Frontier Analysis (SFA) as a parametric approach, this study measured the efficiency level of cost and profit efficiency of the Indonesian Islamic commercial banks. The data were a cross-section and panel data obtained from financial reports established by seven Indonesian Islamic commercial banks. The result of frontier analysis on the efficiency costs showed that the value of sharia banks' average efficiency in Indonesia was approximately $93.41 \%$, while the efficiency of profit resulted in $55.35 \%$. These results suggest that Islamic banks tend to be efficient in controlling costs from the year of 2015 to 2019. It is a worth saying that this study's results contribute to providing fruitful insights for Islamic banks to increase their efficiency by controlling their cost of production such as the cost of funds and cost of operation.
\end{abstract}

Keywords: Financial Costs; Financial Profits; Islamic Banks Efficiency; Stochastic Frontier Analysis 


\section{Introduction}

In the recent decades, the development of Islamic financial industry has been experiencing a significant increase, particularly in Islamic commercial banks. Islamic banking is recognized as the fastest growing institution in the world of banking and finance. The Islamic banking industry has been accepted globally and has changed from a 'small' industry to one of the industries that is worthy of being an alternative model for intermediary institutions since 1970, or more than 25 years ago. Globally, the total annual growth of Islamic banks' assets reach double digits or around 1.6 Trillion Dollars in 2012 (Imam \& Kpodar, 2013).

Islamic banking is present as a financial institution whose function is to facilitate economic mechanisms in the real sector through investment or buying and selling activities, as well as providing savings and banking services for customers based on sharia principles (Maulana \& Rusmita, 2019). In addition, an Islamic Bank collects funds from customers through deposits or investments as well as demand deposits and savings. The funds collected are then invested in the business world through self-investment (non-profit sharing/trade financing) and investment with other parties (profit sharing/investment financing) (Ascarya, \& Yumanita, 2006). The Islamic banking industry in Indonesia has also shown some developments. According to the data established by Financial Services Authority (OJK), these developments can be seen from several financial indicators, financial ratios in Islamic banks, and the increase number of banks and branch offices.

Based on data from the Financial Services Authority (see table 1), during 2015 to December 2019, there was an increase in the amount of assets, third party funds (TPF), and financing channeled by Islamic banks. The highest development was on 2016, in which the asset increased dramatically by $20.28 \%$, TPF by $20.84 \%$, and financing by $16.41 \%$. However, it is also noticed that from 2017 to 2019 the 
development of Islamic banks is gradually decreasing, only TPF that rose to $11.93 \%$ in 2019 from $11.14 \%$ in 2018.

Table 1. Indonesian Islamic Banks Development in 2015 - 2019 (in Billion Rupiah)

\begin{tabular}{lccccc}
\hline $\begin{array}{l}\text { Development } \\
\text { (YoY) }\end{array}$ & 2015 & 2016 & 2017 & 2018 & 2019 \\
\hline Assets & $8.99 \%$ & $20.28 \%$ & $18.97 \%$ & $12.57 \%$ & $9.93 \%$ \\
Third Party Funds & $6.35 \%$ & $20.84 \%$ & $19.89 \%$ & $11.14 \%$ & $11.93 \%$ \\
Financing & $7.06 \%$ & $16.41 \%$ & $15.27 \%$ & $12.17 \%$ & $10.89 \%$ \\
\hline
\end{tabular}

Source: Financial Services Authority (2019)

To deal with the cutthroat competition among banks, Islamic commercial banks are required to have good performance to be able to maintain customers' loyalty that always demand greater profits and good service quality. In order to maintain the customers' trust and loyalty, Islamic banks need to improve their performance, both in terms of financial performance and efficiency. A good performance in the banking industry is generally associated with the level of efficiency achieved by the bank. Banking efficiency is an optimization that reflects the optimal use of inputs to produce maximum output (Saeed \& Saeed, 2018). Empirically, Aldeen et al. (2020) found that banks' efficiency influenced bank performance in Syria. On the other hand, efficiency can show a bank's ability to maintain its sustainability practices, as being researched by Andri et al. (2020) on one of the biggest Islamic banks in Indonesia.

Chang et al. (2017) states that research on banks' efficiency is crucial to providing useful information for government by respecting existing policies and regulations. It also offers fruitful information to maintain and improve managerial performance by identifying each sector with good performance and correcting poor performance. Ur Rehman et al. (2020) mention that providing useful information about banks' efficiency is significantly important to describe the quality of management. Kallel et al. (2019) support the previous research and mention that service quality or cost of operational have positive effect 
on banks' efficiency, even though that is additional cost for the Bank, but good services could generate more third party fund. Therefore, the measurement of efficiency in Islamic banks is considered as an important indicator in looking at the ability of Islamic banks to survive and face intense competition in the Islamic financial industry.

Efficiency is one of the performance parameters that theoretically underlies the entire performance of an organization (Hadad et al., 2003). Efficiency occurs when an organization can get greater profits than the costs incurred for their operations (Nugroho et al., 2019). The ability of banks to produce maximum output using existing inputs is a measure of performance expected by banks. With the input and output allocation identified, it can be further analyzed to see why banks are not achieving efficiency. In the context of banking system, efficiency can be measured in several ways, by looking at the comparison of banking performance indicators and financial ratios. There are also several other methods, namely parametric and non-parametric approaches. The parametric approach includes Stochastic Frontier Analysis (SFA) while non-parametric approaches using the Data Envelopment Analysis (DEA) approach.

According to Nguyen and Pham (2020), an analysis of banking efficiency evaluations is appropriate when using parametric or nonparametric evaluations. This is due to the ability of the two methods that can include various inputs and outputs in their analysis. In addition, differences in unit variables are not a problem, where it could not previously be done by other analytical tools so that parametric and non-parametric efficiency analysis tools are more flexible and can cover a wider range of variables compared to other analysis tools (Sakouvogui \& Shaik, 2020). Parametric and non-parametric methods have several differences, one of the prominent differences is the parametric method of entering random errors on the frontier, while non-parametric methods do not include it. As a consequence, the nonparametric approach cannot take into account macro variable factors such as differences in the size of a bank's assets or other variables that 
can affect the level of efficiency (Hadad et al., 2003). Stochastic Frontier Analysis (SFA) is an analysis firstly introduced by Aigner et al. (1977), while Data Envelopment Analysis (DEA) is a non-parametric analysis which is a development of mathematical linear programming firstly introduced by Charnes et al. (1978).

Several studies examining the efficiency of Islamic banks have been carried out beforehand, such as Hosen and Rahmawati (2016) and Kusmayadi et al. (2017), which states that there is an influence between the input and output components with the level of cost efficiency. The study measures the efficiency level of Islamic banks and profitability of Islamic banks. While research conducted by Hendrawan and Nasution (2018) states that banking efficiency in Indonesia shows figures that are close to $100 \%$, which means it is almost strictly efficient. Moreover, the difference between this study and previous research is that this study will come out with updated data from 2015 to 2019. This research is also more crucial because there are events or evidence from statistical data form Financial Services Authority that the efficiency of Islamic banks has decreased along with the decline in the performance of Islamic banks (see table 1). Hence, this study analyzes the measurement of cost efficiency and profit efficiency of Islamic Commercial Banks (BUS) with the Stochastic Frontier Analysis (SFA) method.

It has been widely acknowledged that SFA has advantages compared to other measurement methods. According to Aigner et al. (1977), the advantages of SFA compared to other models are, first, the involvement of disturbance terms that represent disturbances, measurement errors, and exogenous shocks are out of control. Second, environmental variables are easier to treat, allowing hypothesis testing using statistics, and more easily identify outliers (Silva et al., 2017). In this study, the input and output variables are determined based on the intermediation approach by considering the main function of the bank as financial intermediation (Karray \& Jamel, 2013). The use of inputoutput variables in this study is the price of labor (personnel 
expenses/total assets), the price of funds (profit sharing expenses/total third party funds) and the price of capital (administrative \& general costs and other costs/fixed assets) as input. While the output in this study is total financing and securities. Based on the results of previous research, this study is important to find out how efficient Indonesian Islamic commercial banks are in terms of costs and profits.

Based on the background explained above, this study is directed to scrutinize the cost efficiency and profit efficiency of Islamic commercial banks with financial performance on Islamic banks registered in OJK. This study becomes crucial since the development of Islamic bank market goes slowly in the long run 20 years and the performance decreasing gradually, so the efficiency of Islamic bank need to be examined. Therefore, the present study is conducted to shed some light on the analysis of cost efficiency and profit efficiency levels of Islamic commercial banks in Indonesia in the year of 2015 to 2019 using Stochastic Frontier Analysis (SFA).

\section{Review of Literature}

\section{Banking Efficiency}

Efficiency in a banking system is deemed necessary in supporting its performance to carry out the functional role in allocating financing. This role will certainly affect the level of economic growth, namely ensuring the availability of funding needed for investment expenditure or to run other economic sectors. Banking efficiency can be seen from two sides, namely in terms of cost (cost efficiency) and financial side (profit efficiency). A bank can be seen from the remaining cost (cost efficiency), that is accessible by comparing to the bank that has good operating costs (best practice bank's cost) that can produce the same output and the same technology (Anwar, 2019). While in terms of profit (profit efficiency), the level of efficiency is determined by the ability of a bank to generate profits for each unit of input used (Hendrawan \& Nasution, 2018). 


\section{Input and Output in Efficiency Measurement}

The concept of efficiency calculation is closely related to how to describe the relationship between input and output. To measure efficiency with the SFA approach, it can be done through an outputoriented approach to measuring technical efficiency, and an inputoriented approach to measuring cost efficiency. Technical efficiency is determined by the production frontier, while cost efficiency is measured by the cost frontier (Andor \& Parmeter, 2017). The process of determining input-output in a bank is important, especially because there is no clear consensus in defining input and output variables in measuring bank efficiency. Berger and Hannan (1998) explains that defining the relationship between input and output in the financial activities of a financial institution can be undertaken with several approaches, including Assapproach, Production approach, and Intermediation approach.

The determination of inputs and outputs in measuring banking efficiency depends on the characteristics of the banking operations themselves. This study is using intermediation approach, where funds are inputs and financing is output. This study employs an intermediation approach where the price of labor (personnel expenses/total assets), the price of funds (profit sharing expenses/total third party funds), and the price of capital (administrative \& general costs and other costs/fixed assets) as input. While the output in this study is total financing and securities (Tahir \& Haron, 2010).

Mokhtar et al. (2006) investigated the banks' efficiency in Malaysia during 1997-2013 period by using SFA. The empirical findings show that the efficiency of the overall Islamic Banks increased, while the conventional bank was stable. However, the value of the efficiency of Islamic Banks tends to be lower than conventional banks. In addition, the foreign Islamic Bank is also more efficient than the domestic banks. An empirical study by Srairi (2010) compared the cost efficiency and profit efficiency of conventional banks and Islamic banks in GCC countries in 1997-2007. The results showed that the cost 
efficiency score (56\%) was lower than the profit efficiency score $(71 \%)$. This result indicates that these countries are more efficient in increasing profits than controlling costs. The dependent variable in this study is total cost and total profit. The input variables used in this study included labor prices, funds prices, and capital prices. While the output variable used was total net loans and other productive assets.

In a similar direction, Hosen and Rahmawati (2016) had inspected the level of efficiency and profitability at five Islamic banks in Indonesia using the SFA method. The results show that Bank Syariah Mandiri had the highest level of efficiency than the other four banks. This study states that the efficiency was influenced by the cost of human resources, the cost of sharing, and financing. In addition, Bank Syariah Mandiri achieved the highest level of profitability; one of the factors that influence it was the BOPO ratio. The input variables used were price of labor and price of fund, while the output variables in this study were total financing and securities which are owned. Moreover, using SFA, banks' efficiency had also been researched by Hendrawan and Nasution (2018). In general, they found that Indonesia's banking system from 2008 to 2017 was classified as inefficient, based on its average efficiency score. Specifically, the results also showed that from the total of 21 banks in Indonesia, eleven banks were classified in the stable category while ten banks were considered as inefficient.

Furthermore, Kallel et al. (2019) examined the level of banks' efficiency in Morocco and Tunisia, and investigated the factors that influence it in the period of 2005 to 2014. The results depicted that banks in Morocco had a higher level of efficiency than banks in Tunisia. The research further stated that the changes in the level of banks' efficiency in the two countries were positively related to banks' service quality, as well as banks' capitalization and GDP growth negatively. Although it examines banks' efficiency, the present study differs from the existing literature in several points. First, this study provides updated-data, especially on the Islamic banks in Indonesia. Second, the procurement of this study is also related to current issues about the 
decline in the performance of Islamic banks in Indonesia, so the level of efficiency at these banks needs to be examined.Therefore, this study is directed to examine the cost efficiency and profit efficiency of Islamic commercial banks in Indonesia from 2015 to 2019.

\section{Research Method}

\section{Sample Selection and Data Sources}

This study was conducted to examine the efficiency of Islamic commercial banks in Indonesia. To seek the empirical answers, this study employed panel data obtained from secondary data in forms of Islamic banks' financial reports published on the Financial Services Authority's website from 2015 to 2019. The data were purposively gathered from financial reports established by Islamic banks in Indonesia based on some criteria, i.e. (1) having been or are still operating in 2015 to 2019, (2) establishing regular financial reports, (3) having information about the total costs incurred by the bank, labor prices, fund prices, capital prices, total financing, and securities, and (4) never experiencing losses during the observation period so that there is no bias in the results of this study as caused by variable selection. Based on these requirements, table 2 presents seven Islamic commercial banks that meet the criteria which financial reports are used as sample in this study.

Table 2. Sample and Data Sources

\begin{tabular}{cll}
\hline No & Code & Banks \\
\hline 1 & BMI & Bank Muamalah Indonesia \\
2 & BRIS & Bank Rakyat Indonesia Syariah \\
3 & BNIS & Bank Negara Indonesia \\
4 & BSM & Bank Syariah Mandiri \\
5 & BMS & Bank Mega Syariah \\
6 & BSB & Bank Syariah Bukopin \\
7 & BCAS & Bank Cental Asia Syariah \\
\hline
\end{tabular}

Source: Financial Services Authority (2019) 


\section{Empirical Model of SFA}

SFA empirical model can be different from the properties of the commonly used model (Kumbhakar et al., 2019). The regression formula of the model is presented as follows:

$\operatorname{InTC}_{\mathrm{kit}}=\beta_{0}+\sum_{l=0}^{2} \beta \operatorname{IIn} p_{\mathrm{it}}+\sum_{i=0}^{2} \alpha_{\mathrm{k}} \operatorname{Iny}_{\mathrm{kit}}-\mu_{\mathrm{it}}+\mathrm{v}_{\mathrm{it}}$

in which:

$\mathrm{TC}_{\text {kit }}=$ Total Cost at the bank $\mathrm{i}$

$P_{i t} \quad=$ Number of outputs (P1: financing, P2: securities)

$\mathrm{Y}_{\mathrm{kit}} \quad=$ Amount of input $(\mathrm{Y} 1$ : Labor Price, $\mathrm{Y} 2$ : Fund Price, $\mathrm{Y}$ 3: Capital Price)

$\mu_{\text {it }} \quad=$ Inefficiency

$\mathrm{v}_{\text {it }} \quad=$ noise effect

$\varepsilon_{\text {it }} \quad=$ Random Error

$\alpha ; \alpha_{k} ; \beta i=$ Estimated parameter

Meanwhile, the cost efficiency model is postulated as follows:

CostEFF ${ }^{b}={\frac{\hat{C}}{\hat{C}^{b}}}^{\min }=\frac{\exp \left[f\left(W^{b}, Y^{b}, Z^{b}, V^{b}\right) X_{\text {exp }}\left[\operatorname{In} \widehat{U}_{c}^{\text {min }}\right]\right.}{\exp \left[f\left(W^{b}, Y^{b}, Z^{b}, V^{b}\right) X_{\exp }\left[\operatorname{In} \widehat{U}_{c}^{b}\right]\right.}=\frac{\widehat{U}_{c}^{\text {min }}}{\widehat{U}_{c}^{b}}$

where $\widehat{U}_{c}^{\mathrm{min}}$ is the minimum $\widehat{U}_{c}^{b}$ value of each financial institution in the sample.

$\operatorname{InTP}_{\mathrm{kit}}=\beta_{0}+\sum_{l=0}^{2} \beta \operatorname{iIn} p_{\mathrm{it}}+\sum_{i=0}^{2} \alpha_{\mathrm{k}}$ Iny $_{\mathrm{kit}}-\mu_{\mathrm{it}}+\mathrm{v}_{\mathrm{it}}$

in which:

$\mathrm{TP}_{\text {kit }}=$ Total Profit at the bank

$\mathrm{P}_{\text {it }} \quad=$ Number of outputs (P1: financing, P2: securities)

$\mathrm{Y}_{\mathrm{kit}}=$ Amount of input $(\mathrm{Y} 1$ : Labor Price, $\mathrm{Y} 2$ : Fund Price, $\mathrm{Y}$ 3: Capital

Price)

$\mu_{\text {it }} \quad=$ Inefficiency

$v_{\text {it }} \quad=$ noise effect

$\varepsilon_{\text {it }}=$ Random Error

Vol. 5 No. 3, September - December 2020 
$\alpha ; \alpha_{k} ; \beta i=$ Estimated parameter

Moreover, the stochastic profit is written as follows:

$\mathrm{ALT} \Pi \mathrm{EFF} b=\frac{a \pi}{a \pi^{\max }}{ }^{b}=\frac{\exp \left[f\left(W^{b}, Y^{b}, Z^{b}, V^{b}\right) X_{\exp }\left[\operatorname{In} \widehat{U}_{a \pi}^{b}\right]-\theta\right.}{\exp \left[f\left(W^{b}, Y^{b}, Z^{b}, V^{b}\right) X_{\exp }\left[\operatorname{In} \widehat{U}_{a \pi}^{\max }\right]-\theta\right.}$

The maximum value of $u_{\pi}$ is the maximum value of $u_{\pi}^{\underline{b}}$ in the sample.

\section{Variable Measurements}

This study made use of intermediation approach that is more appropriate to evaluate the performance of financial institutions. This is due to its characteristics as a financial intermediation that raises funds from public with excess funds to the people who need financing. Variables involved in this study are defined as follows:

Table 3. Variables' Operational Definitions

Variable Definition Formula

Dependent Variables

\begin{tabular}{lll}
\hline TC :Total Cost & $\begin{array}{l}\text { Total costs according to Srairi } \\
\text { (2010) are both interest costs and } \\
\text { non-interest costs in the } \\
\text { efficiency function (in Islamic } \\
\text { banks, interest expense is profit } \\
\text { distributed to depositors). }\end{array}$ & $\begin{array}{l}\text { Profit sharing for fund } \\
\text { owners + wadiah } \\
\text { bonuses + personnel } \\
\text { expenses + } \\
\text { administrative } \\
\text { expenses + other } \\
\text { operating expenses }\end{array}$ \\
п: Total Profit & $\begin{array}{l}\text { Srairi (2010) states that total } \\
\text { profit is total return before tax } \\
\text { costs. }\end{array}$ & $\begin{array}{l}\text { Total revenue - total } \\
\text { costs }\end{array}$ \\
\end{tabular}

Independent Variables (Variable Input)

Y1 : Labor Labor costs according to Srairi Personnel expenses /

Costs (2010) are costs incurred by total assets

banks to pay labor. 


\begin{tabular}{|c|c|c|}
\hline \multicolumn{2}{|c|}{ Variable Definition } & Formula \\
\hline \multicolumn{3}{|c|}{ Independent Variables (Variable Input) } \\
\hline $\begin{array}{l}\text { Y2 : The Cost } \\
\text { of Funds }\end{array}$ & $\begin{array}{l}\text { The cost of funds according to } \\
\text { Srairi (2010) is calculated by } \\
\text { dividing interest costs with total } \\
\text { deposits (in Islamic banks, } \\
\text { interest expenses are profits } \\
\text { distributed to depositors). }\end{array}$ & $\begin{array}{l}\text { Profit sharing for fund } \\
\text { owners }+ \text { wadiah } \\
\text { bonuses/ total third } \\
\text { party funds }\end{array}$ \\
\hline $\begin{array}{l}\text { Y3: } \\
\text { Operational } \\
\text { Costs }\end{array}$ & $\begin{array}{l}\text { Capital costs according to Srairi } \\
(2010) \text { is the ratio of non-interest } \\
\text { costs divided by total fixed } \\
\text { assets. }\end{array}$ & $\begin{array}{l}\text { Administrative } \\
\text { expenses }+ \text { other } \\
\text { operating expenses/ } \\
\text { total fixed assets }\end{array}$ \\
\hline \multicolumn{3}{|c|}{ Independent Variables (Variable Output) } \\
\hline $\begin{array}{l}\text { P1 : Total } \\
\text { Financing }\end{array}$ & $\begin{array}{l}\text { According to Archer et al. (in } \\
\text { Srairi, 2010) total financing } \\
\text { includes murabahah receivables, } \\
\text { mudaraba investments, } \\
\text { musharaka investments, interest- } \\
\text { free loans (Qard), loans with } \\
\text { service fees, and other } \\
\text { operations. }\end{array}$ & $\begin{array}{l}\text { Murabahah receivables } \\
+ \text { salam receivables + } \\
\text { istishna receivables + } \\
\text { qardh receivables + } \\
\text { other receivables + } \\
\text { Financing + Ijarah } \\
\text { assets }\end{array}$ \\
\hline P2 : Securities & $\begin{array}{l}\text { Securities are letters that have } \\
\text { properties and values such as } \\
\text { cash and can be exchanged for } \\
\text { cash (Rasjimwiraatmadja in } \\
\text { Srairi, 2010) }\end{array}$ & $\begin{array}{l}\text { Securities owned by } \\
\text { banks }\end{array}$ \\
\hline
\end{tabular}

Source: Srairi (2010)

\section{Stages of Data Collection and Analysis}

The procedures of data collection and analysis are explained in a sequence. First, the data collection process was begun by compiling Islamic commercial banks' financial reports from 2015 to 2019 to examine the variables of costs, total profits, and input output prices. Second, the authors specified cost and profit function using intermediation approach by considering that bank is an intermediary 
institution that uses funds as input and channels them as financing. The cost and profit function model that will be estimated is the translog function. Third, as the data analysis, cost function estimation and testing was conducted using Eviews software. In this stage, the efficiency was from zero to one. The calculation of the cost efficiency score in the frontier equation, which is the result of $E F F_{i}$, is the ratio of the minimum costs that may occur to in actual costs. Meanwhile, the translog function was calculated based on the difference between the actual cost and the minimum cost for an observation. Finally, after the cost function model and the profit function are estimated, the efficiency value is calculated by taking the residual value, which is the difference in the value of the estimated total cost and the actual cost value. Likewise, with the profit function, the calculation of the efficiency value is carried out using the residual value generated from the banking profit function. The most efficient bank is the bank that has the smallest residual value among all banks in the same period.

\section{Results}

\section{Descriptive Statistics}

Table 4 depicts the descriptive statistics results of variables involved in this study. It indicates that Total Cost variable has an average value of IDR. 2.297.380.776.681.77, which means that the total cost incurred by all banks is the exact number with a maximum value is IDR 6.819.994.000.000. Meanwhile, the average value of Profit is IDR 236.654.908.784.03, with a maximum value is IDR 1,809,264,000,000. As shown in the data, the profit of Islamic bank is lower than the cost.

As for input variables, first, the Labor Cost has average of $1.82 \%$ with a maximum value of $4.78 \%$. Second, the Cost of Funds results in average of $4.75 \%$ with a maximum value $7.88 \%$. Third, the Operational Costs yields $22 \%$ of average with maximum value $78.8 \%$. With regards to output variables, the Total Financing reaches IDR 29.307.117.480.262.32 in average with a maximum value IDR 127.712.929.000.000. Lastly, the average value of Securities is 
amounting to IDR 4.767.108.582.038.74, with a maximum value IDR 21.088.128.000.000.

Table 4. Descriptive Statistics Results

\begin{tabular}{lrrrrr}
\hline & $\mathrm{N}$ & Minimum & \multicolumn{1}{c}{ Maximum } & \multicolumn{1}{c}{ Mean } & \multicolumn{1}{c}{ Std. Deviation } \\
\hline $\mathrm{TC}$ & 35 & 302454760972 & 6819994000000 & 2297380776681.77 & 1960083580111.633 \\
$\mathrm{TP}$ & 35 & 2099379461 & 1809264000000 & 236654908784.03 & 353273231482.074 \\
Y1 & 35 & .0107 & .0478 & .018271 & .0067251 \\
Y2 & 35 & .0226 & .0722 & .047587 & .0127306 \\
Y3 & 35 & .0121 & .7881 & .228003 & .1916915 \\
P1 & 35 & 2935731695921 & 127712929000000 & 29307117480262.32 & 34021578017687.363 \\
P2 & 35 & 49500000000 & 21088128000000 & 4767108582038.74 & 5238539110444.929 \\
Valid N & 35 & & & & \\
(listwise) & & & & & \\
\hline
\end{tabular}

Level of Cost Efficiency using Stochastic Frontier Analysis

The data analysis was performed by means of Eviews 6 software using Maximum Likelihood (MLE) method. With regards to the frontier function as depicted in table 5, the estimation results and the form of a prediction model of the level of cost efficiency on the Islamic commercial bank is written as follows:

$\operatorname{lnTC}=12.13933+8.072982 \ln Y 1+10.30334 \ln Y 2-$

$0.090804 \ln Y 3+0.371652 \ln Q 1+0.140343 \ln Q 2$

Table 5. Formation Results in Translog Cost Function with MLE

Variable Coefficient Std. Error t-Statistic Prob.

\begin{tabular}{lllll}
\hline Constant & 12.13933 & 4.030074 & 3.012185 & 0.0062 \\
Labor costs & 8.072982 & 4.570174 & 1.766450 & 0.0906 \\
The cost of funds & 10.30334 & 3.073899 & 3.351879 & 0.0028 \\
operational costs & -0.090804 & 0.358834 & -0.253052 & 0.8025 \\
Total Financing & 0.371652 & 0.131874 & 2.818230 & 0.0098 \\
Securities & 0.140343 & 0.036961 & 3.797040 & 0.0009 \\
\hline
\end{tabular}

Vol. 5 No. 3, September - December 2020 
In the regression equation above, the TC constant is 12.13933 . Based on table 5, it is known that the input of labor prices shows a positive value of the regression coefficient of 8.072982, indicating that if the exponent of the labor force price has increased by one unit, then the total cost will increase by 8.072982 . The cost of fund shows the value of the regression coefficient 10.30334, which means that if the component price of funds has increased by one unit, the total cost will increase by 10.30334. Nevertheless, the last input variable which is cost of operation shows negative value of the regression coefficient 0.090804, indicating that if the exponent of the capital price has increased by one unit, then the total cost will decrease by 0.090804 but the variable are not significant. The total financing as portrayed in the table has a regression coefficient of 0.371652 , which means that if the total exponent of financing has increased by one unit, then the total cost will increase by 0.543238 . Moreover, the value of securities shows a positive value of the regression coefficient of 0.140343 , which means that if the exponents of the securities have increased by one unit, then the total cost will increase by 0.140343 .

\section{Cost Efficiency Analysis of Islamic Commercial Banks in 2015 - 2019}

The average cost efficiency for all samples in this study per year from 2015 to 2019 is illustrated in table 6. The average cost efficiency during the study period is 0.9341 or amounting to $93.41 \%$. This value is considered good because it is approaching 1, which means that Indonesian sharia commercial bank is in an almost efficient condition. It is also noticed that the entire study sample experienced cost inefficiencies of 0.0659 (6.59\%) during the 2015 to 2019, meaning that sharia commercial banks can reduce costs by $6.59 \%$, thus they can be more efficient. In contrast to research conducted by Rahmawati (2015) where the average cost efficiency of a Sharia Commercial Bank in its research sample is 0.8538 or $85.38 \%$, this finding suggests that a sharia commercial bank can reduce costs by 0.1462 (14.62\%). It shows that the performance of sharia commercial banks in the 2015 to 2019 were still 
better than in 2013 to 2015 as seen from the cost management as reported by Rahmawati (2015). From table 6 it is also portrayed that the highest average of cost efficiency was in the year of 2018, which is $0.9556(95.56 \%)$. It indicates that the sharia banks involved in this study could efficiently manage their costs. Meanwhile, the smallest average was in 2019 with $0.876(87.6 \%)$ value.

Table 6. Cost Efficiency of Islamic Banks in 2015 to 2019

\begin{tabular}{llllll}
\hline & $\mathbf{2 0 1 5}$ & $\mathbf{2 0 1 6}$ & $\mathbf{2 0 1 7}$ & $\mathbf{2 0 1 8}$ & $\mathbf{2 0 1 9}$ \\
\hline Bank Muamalat Indonesia & 0.9228 & 0.9979 & 0.9295 & 0.9547 & 0.8955 \\
Bank BRI Syariah & 0.9888 & 0.9368 & 0.9699 & 0.9472 & 0.8427 \\
Bank BNI Syariah & 0.9472 & 0.9569 & 0.9777 & 0.9875 & 0.8943 \\
Bank Syariah Mandiri & 0.8845 & 0.9937 & 0.9550 & 0.9333 & 0.7664 \\
Bank Mega Syariah & 0.9525 & 0.9671 & 0.9187 & 0.9816 & 0.9806 \\
Bank Syariah Bukopin & 0.9956 & 0.8785 & 0.9344 & 0.9158 & 0.8927 \\
Bank BCA Syariah & 0.9361 & 0.8986 & 0.9285 & 0.9690 & 0.8600 \\
\hline Average per year & 0.9468 & 0.9471 & 0.9448 & 0.9556 & 0.8760 \\
\hline Total average & \multicolumn{5}{c}{0.9341} \\
\hline
\end{tabular}

Moreover, table 7 shows the average cost efficiency obtained by each Islamic banks in the period of 2015-2019. It depicts that Bank Syariah Mega was the most cost-efficient Islamic commercial bank since its cost efficiency score was $96.01 \%$. In the contrary, the lowest efficiency rate during the period of 2015-2019 was experienced by Bank Syariah Mandiri (90.66\%). It can be seen from the table that as the most cost efficient bank, Bank Mega Syariah has the highest value of efficiency cost and it increased per year, as depicted in its input. At least, this finding confirms what have been reported by Zuhroh et al. (2015) that the growth of a bank performance is indicated by its cost efficiency. The finding further implies that greater number of cost efficiency shows that the bank still considers to minimize the cost production. 
Table 7. Cost Efficiency Average of Banks

\begin{tabular}{lc}
\hline & Cost Efficiency \\
\hline Bank Muamalat Indonesia & 0.9401 \\
Bank BRI Syariah & 0.9371 \\
Bank BNI Syariah & 0.9527 \\
Bank Syariah Mandiri & 0.9066 \\
Bank Mega Syariah & 0.9601 \\
Bank Syariah Bukopin & 0.9234 \\
Bank BCA Syariah & 0.9184 \\
\hline Average & 0.9341 \\
\hline
\end{tabular}

\section{Level of Profit Efficiency using Stochastic Frontier Analysis}

Table 8 presents the result of translog profit function analysis using Eviews 6 software with Maximum Likelihood (MLE) method. Based on the table, the formulation is postulated as follows:

$\ln \mathrm{TP}=13.34370+(-72.60607) \ln \mathrm{Y} 1+60.07291 \ln \mathrm{Y} 2+(-1.119777) \ln \mathrm{Y} 3+$ $(-0.052859) \ln \mathrm{P} 1+0.432555 \ln \mathrm{P} 2$

Table 8. Formation Results of the Translog Profit Function with MLE

\begin{tabular}{lcccc}
\hline Variable & Coefficient & Std. Error & t-Statistic & Prob. \\
\hline Constant & 13.34370 & 29.72092 & 0.448967 & 0.6577 \\
Labor costs & -72.60607 & 33.70404 & -2.154224 & 0.0419 \\
The cost of funds & 60.07291 & 22.66934 & 2.649963 & 0.0143 \\
operational costs & -1.119777 & 2.646324 & -0.423144 & 0.6761 \\
Total Financing & -0.052859 & 0.972543 & -0.054351 & 0.9571 \\
Securities & 0.432555 & 0.272580 & 1.586894 & 0.1262 \\
\hline
\end{tabular}

The constant of Total Profit (TP) is 13.34370. In the results of the frontier function as described in table 8, labor price input has a regression coefficient of -72.60607 and shows a negative value. This means that if the exponent of labor prices has increased by one unit, then the total profit will decrease by -72.60607 . The fund price shows a 
positive value and has a regression coefficient of 60.07291 which indicates that if the exponent of the price of funds has increased by one unit, then the total profit will increase by 60.07291 . The last input variable in the form of capital price shows a negative value, the regression coefficient of -1.119777 shows that if the exponent of operational cost increases by one unit, then the Total Profit will decrease by 1.119777 . Furthermore, the total financing variable has a regression coefficient of -0.052859 and shows a negative value, which indicates that if the total exponent of financing has increased by one unit, then the total profit will decrease by 0.052859 . Lastly, the value of securities is positive and has a regression coefficient of 0.432555 which means that if the exponents of the securities have increased by one unit, then the total profit will increase by 0.432555 .

Table 9. Islamic Commercial Banks' Profit Efficiency in 2015-2019

\begin{tabular}{llllll}
\hline & 2015 & 2016 & 2017 & 2018 & 2019 \\
\hline Bank Muamalat Indonesia & 0.2179 & 0.3584 & 0.9152 & 0.7110 & -0.6277 \\
Bank BRI Syariah & 0.6075 & 0.3680 & 0.7321 & 0.5411 & 0.7023 \\
Bank BNI Syariah & 0.7733 & 0.8472 & 0.6797 & 0.8686 & 0.4316 \\
Bank Syariah Mandiri & 0.2111 & 0.8976 & 0.7609 & 0.7676 & 0.1020 \\
Bank Mega Syariah & 0.9680 & 0.3618 & 0.7135 & 0.7866 & 0.8937 \\
Bank Syariah Bukopin & 0.0246 & -0.3932 & 0.2031 & -0.3686 & 0.7969 \\
Bank BCA Syariah & 0.9838 & 0.7891 & 0.9879 & 0.9094 & 0.8514 \\
\hline Average per year & 0.5409 & 0.4613 & 0.7132 & 0.6023 & 0.4500 \\
\hline Total average & \multicolumn{5}{c}{0.5535} \\
\hline
\end{tabular}

Furthermore, the profit efficiency of Islamic commercial banks in the year of 2015 to 2019 is presented in table 9. It is depicted that the average of their profit efficiency in 2015 to 2019 was 0.5535 , meaning that the sharia banks generated $55.35 \%$ of the potential profit obtained through a good management. Then, the remaining $44.65 \%$ was considered as profit inefficiency. The highest average of sharia banks' profit efficiency was in 2017 and 2018; however, in 2019 they experienced a fairly decreased efficiency. This finding is similar to the 
result reported by Hardianto and Wulandari (2016). From table 9 it is also depicted that 2016 was the year with the lowest profit efficiency obtained by the sharia commercial banks in Indonesia.

In a detailed description, the average of profit efficiency of each bank is depicted in table 10. It can be seen that Bank Muamalat was the most inefficient sharia commercial banks with the lowest score of profit efficiency $(31.50 \%)$. On the other hand, BCA Syariah was recognized as the most profitable bank in 2015 to 2019 . Having seen from the point of view of stochastic frontier analysis, it was shown that there were no sharia commercial banks in Indonesia performed a stable performance, since they experienced a fluctuating profit efficiency achievements.

Table 10. Profit Efficiency Average of Each Bank

\begin{tabular}{lc}
\hline & Profit Efficiency \\
\hline Bank Muamalat Indonesia & 0.3150 \\
Bank BRI Syariah & 0.5902 \\
Bank BNI Syariah & 0.7200 \\
Bank Syariah Mandiri & 0.5479 \\
Bank Mega Syariah & 0.7447 \\
Bank Syariah Bukopin & 0.0526 \\
Bank BCA Syariah & 0.9043 \\
\hline Average & 0.5535 \\
\hline
\end{tabular}

\section{Discussion}

This study shows several compelling results. In comparison to the results of cost and profit efficiency, there are several Islamic commercial banks that experience fluctuating values from 2015 to 2019 . The decrease of cost efficiency is not followed by an increase in the value of profit efficiency, and the value of profit efficiency continues to increase and decrease, or be volatile in the year of 2015 to 2019. It indicates that the Islamic commercial banks involved in this study experience problems in the operational activities, since they does not 
operate efficiently in the context of costs or profits. The detailed information of cost and profit efficiency values of the sharia banks is presented in table 11.

Table 11. Cost and Profit Efficiency of Sharia Banks in 2015 to 2019

\begin{tabular}{lcc}
\hline & Cost Efficiency & Profit Efficiency \\
\hline Bank Muamalat Indonesia & 0.9401 & 0.3150 \\
Bank BRI Syariah & 0.9371 & 0.5902 \\
Bank BNI Syariah & 0.9527 & 0.7200 \\
Bank Syariah Mandiri & 0.9066 & 0.5479 \\
Bank Mega Syariah & 0.9601 & 0.7447 \\
Bank Syariah Bukopin & 0.9234 & 0.0526 \\
Bank BCA Syariah & 0.9184 & 0.9043 \\
\hline Average & 0.9341 & 0.5535 \\
\hline
\end{tabular}

In a more detailed comparison, if it is seen from the cost efficiency, the lowest value was obtained by Bank Mandiri Syariah (see table 12). Hence, it is concluded that its financing outputs require quite expensive inputs, so that it causes the bank to have the lowest value of cost efficiency. The highest cost efficiency value was owned by Bank Mega Syariah by 96.01\%. Bank Mega Syariah has the highest cost efficiency value, meaning that it could optimize the expenditure for financing outputs. However, as seen from table 10, Bank Mega Syariah was still unable to optimize costs incurred to generate maximum profits.

With regards to profit efficiency, the lowest value was owned by Bank Muamalat with $31.50 \%$, meaning that the costs incurred by Bank Muamalat had not been able to produce high profits. In other words, the costs incurred have not been efficient to generate profits. Based on the cost efficiency of Bank Muamalat, the value was higher than the average efficiency. It suggests that Bank Muamalat still have good management to control the cost of production, sharing costs, and the cost of fund, but it must be more efficient to generate a good quality of financing. On the contrary, the highest value of profit efficiency 
performed by BCA syariah. It implies that the costs incurred for BCA Syariah operations are able to generate more profit than other Islamic commercial banks.

Table 12. Summary of Cost and Profit Efficiency

Cost Efficiency

\begin{tabular}{ccc}
\hline Average & Best Value & Lowest Value \\
\hline $93.41 \%$ & $96.01 \%$ & $90.66 \%$ \\
& (Bank Mega Syariah) & (Bank Syariah Mandiri) \\
\hline
\end{tabular}

Profit Efficiency

\begin{tabular}{ccc}
\hline Average & Best Value & Lowest Value \\
\hline $55.35 \%$ & $90.04 \%$ & $31.50 \%$ \\
& (BCA Syariah) & (Bank Muamalat) \\
\hline
\end{tabular}

Above all, the level of cost efficiency at Islamic commercial banks in Indonesia is categorized as good (an average of 93.41\%). However, the profit efficiency is still far from 100\% (an average of 55.35\%). Several factors contribute to the situation, including the lack of capital or assets owned by Islamic commercial banks. The results of this study suggest that Islamic commercial banks in Indonesia need to increase their assets in order to continue expanding the market. Obtaining third party funds must also be optimized by a sharia commercial bank. In addition, they must continuously make product innovations that are attractive to customers and in accordance with customer needs. As a result, their customers' trust will be increased and they do not turn to conventional banks. Last but not least, Islamic commercial banks must also cut costs that are less important and allocate them to something more useful.

\section{Conclusion}

In conclusion, the results of this study reveal that the average values of Indonesian Islamic banks' cost efficiency is considered as good, which means they had performed efficiently. On the other hand, 
the results further portray that they had not been able to optimize potential profits, and in the same way, they failed to minimize costs to produce the same inputs from the year of 2015 to 2019. In other words, this study indicates that having good cost efficiency does not generate a high income. Despite of the compelling results, the authors acknowledge that this study is limited in some ways. It does not explain factors that may contribute to sharia banks' cost and profit efficiency, nor does the data only last for five years. Therefore, further studies are suggested to need to examine similar research area by involving multiple data sample, both in terms of objects and length of period. Future inquiries can also add other related variables to cost and profit efficiency by using mixed tool such as SFA and regression.

\section{References}

Aigner, D., Lovell, C. A. K., \& Schmidt, P. (1977). Formulation and estimation of stochastic frontier production function models. Journal of Econometrics, 6(1), 21-37. https:/ / doi.org/https://doi.org/10.1016/0304-4076(77)90052-5

Aldeen, K. N., Herianingrum, S., \& Al Agawany, Z. M. W. (2020). Islamic vs. Conventional Banks in Syria: Analysis of Financial Performances. Shirkah: Journal of Economics and Business, 5(1), 126.

Andor, M., \& Parmeter, C. (2017). Pseudolikelihood estimation of the stochastic frontier model. In T. K. Bauer, W. Leininger, V. Clausen, R. Döhrn, M. Frondel, \& J. Kluve (Eds.), Applied Economics 49(55). Ruhr-Universität Bochum (RUB), Department of Economics Universitätsstr. 150, 44801 Bochum, Germany. https://doi.org/http://dx.doi.org/10.4419/86788804

Andri, Suryanto, T., Ghofur, R. A., \& Anggraeni, E. (2020). Analysis of Sharia Innovation Strategic and Efficiency towards Sustainable Ability Shariah Mandiri Banks in Lampung. JEBIS Jurnal Ekonomi Dan Bisnis Islam, $6(1)$, 20-41. https://doi.org/10.20473/jebis.v6i1.18712

Anwar, M. (2019). Cost efficiency performance of Indonesian banks over the recovery period: A stochastic frontier analysis. The Social 
Science Journal,

$56(3)$,

377-389.

https://doi.org/https://doi.org/10.1016/j.soscij.2018.08.002

Ascarya \& Yumanita, D. (2006). Analisis efisiensi perbankan syariah di Indonesia dengan Data Envelopment Analysis. TAZKIA Islamic Finance and Business Review, 1(2), 1-32. https://doi.org/https://doi.org/10.1017/CBO9781107415324.0 04

Berger, A. N., \& Hannan, T. H. (1998). The efficiency cost of market power in the banking industry: A test of the "quiet life" and related hypotheses. Review of Economics and Statistics, 80(3), 454465.

Chang, M., Jang, H. B., Li, Y. M., \& Kim, D. (2017). The relationship between the efficiency, service quality and customer satisfaction for state-owned commercial Banks in China. Sustainability (Switzerland), 9(12), 2163. https:/ / doi.org/10.3390/su9122163

Charnes, A., Cooper, W. W., \& Rhodes, E. (1978). Measuring the efficiency of decision making units. European Journal of Operational Research, 2, 429-444.

Hadad, M. D., Hall, M. J., Kenjegalieva, K. A., Santoso, W., \& Simper, R. (2011). Banking efficiency and stock market performance: an analysis of listed Indonesian banks. Review of Quantitative Finance and Accounting, 37(1), 1-20. https://doi.org/10.1007/s11156-0100192-1

Hardianto, D. S., \& Wulandari, P. (2016). Islamic bank vs conventional bank: intermediation, fee based service activity and efficiency. International Journal of Islamic and Middle Eastern Finance and Management., 9(2), 296-311. https:// doi.org/10.1108/IMEFM-012015-0003

Hendrawan, R., \& Nasution, A. A. (2018). Assessing Banking Profit Efficiency Using Stochastic Frontier Analysis. Journal of Finance and Banking Review, 3(4), 67-76.

Hosen, M. N., \& Rahmawati, R. (2016). Efficiency and Profitability in The Indonesian Islamic Banking Industry. 8(1), 33-48. Al-Iqtishad: Jurnal Ilmu Ekonomi Syariah, 8(1), 33-48. https://doi.org/10.15408/aiq.v8i1.2507

Imam, P., \& Kpodar, K. (2013). Islamic banking: how has it expanded? Emerging Markets Finance and Trade, 49(6), 112-137. https:/ / doi.org/10.2753/REE1540-496X490607 
Kallel, H., Hamad, S. B., \& Triki, M. (2019). Modeling the efficiency of Tunisian and Moroccan banks using the SFA approach. International Journal of Productivity and Performance Management, 68(5), 879-902. https:/ / doi.org/10.1108/IJPPM-03-2018-0099

Karray, S. C., \& Jamel, eddine C. (2013). Bank size and efficiency in developing countries: intermediation approach versus value added approach and impact of non-traditional activities. Asian Economic and Financial Review, 3(5), 593.

Kumbhakar, S., Peresetsky, A., Shchetynin, Y., \& Zaytsev, A. (2019). Technical efficiency and inefficiency: SFA misspecification. ArXiv Preprint ArXiv:1902.02824.

Kusmayadi, D., Badruzaman, J., \& Firmansyah, I. (2017). Efficiency and profitability of Islamic banks in Indonesia. Advanced Science Letters, 23(9), 8807-8812. https:/ / doi.org/10.1166/asl.2017.9975 Maulana, M. R., \& Rusmita, S. A. (2019). Bank Fundamentals and Equity Financing in Indonesia. International Journal of Innovation, Creativity and Change, 9(8), 197-216.

Mohamad, S., Hassan, T., \& Bader, M. K. I. (2008). Efficiency of conventional versus Islamic Banks: international evidence using the Stochastic Frontier Approach (SFA). Journal of Islamic Economics, Banking and Finance, 4(2), 107-130.

Mokhtar, H. S. A., Abdullah, N., \& Al-Habshi, S. M. (2006). Efficiency of Islamic Banking in Malaysia. Journal of Economic Cooperation 27, 2, 37-70. http:// kantakji.com/media/7403/b300.pdf

Nguyen, P. H., \& Pham, D. T. B. (2020). The cost efficiency of Vietnamese banks-the difference between DEA and SFA. Journal of Economics and Development, 22(2), 209-227. https:/ / doi.org/10.1108/JED-12-2019-0075

Nugroho, L., Badawi, A., \& Hidayah, N. (2019). Indonesia Islamic Bank Profitability 2010-2017. Shirkah: Journal of Economics and Business, 4(1), 75-97.

Rahmawati, R. (2015). Strategi peningkatan efisiensi biaya pada bank umum syariah berbasis stochastic frontier approach dan data envelopment analysis. Buletin Ekonomi Moneter Dan Perbankan, 17(4), 457-480. https:/ / doi.org/10.21098/bemp.v17i4.506

Saeed, M. B., \& Saeed, S. K. (2018). Characteristics of Shar1 'ah Supervisory Board, Corporate Governance Mechanisms and Efficiency of Islamic Banks: Evidence from Listed Banks in Asia.

Vol. 5 No. 3, September - December 2020 
Journal of Islamic Business and Management, 8(1), 116-138. https://doi.org/10.26501/jibm/2018.0801-008

Sakouvogui, K., \& Shaik, S. (2020). Impact of financial liquidity and solvency on cost efficiency: evidence from US banking system. Studies in Economics and Finance, 37(2), 391-410. https:// doi.org/10.1108/SEF-04-2019-0155

Silva, T. C., Tabak, B. M., Cajueiro, D. O., \& Dias, M. V. B. (2017). A comparison of DEA and SFA using micro-and macro-level perspectives: Efficiency of Chinese local banks. Physica: A Statistical Mechanics and Its Applications, 469, 216-223. https://doi.org/10.1016/j.physa.2016.11.041

Srairi, S. A. (2010). Cost and profit efficiency of conventional and Islamic banks in GCC countries. Journal of Productivity Analysis, 34(1), 45-62. https:// doi.org/10.1007/s11123-009-0161-7

Tahir, Z. M., \& Haron, S. (2010). Cost and profit efficiency of Islamic banks: international evidence using the stochastic frontier approach. Banks and Bank Systems, 5(4), 78-83.

Wanke, P., Tsionas, M. G., Chen, Z., \& Antunes, J. J. M. (2020). Dynamic network DEA and SFA models for accounting and financial indicators with an analysis of super-efficiency in stochastic frontiers: An efficiency comparison in OECD banking. International Review of Economics \& Finance, 69, 456-468. https://doi.org/10.1016/j.iref.2020.06.002

Zuhroh, I., Ismail, M., \& Maskie, G. (2015). Cost Efficiency of Islamic Banks in Indonesia-A Stochastic Frontier Analysis. Procedia-Social and Behavioral Sciences, 21(1), 1122-1131. https://doi.org/10.1016/j.sbspro.2015.11.150 